chemistry. in the Department of Biochemistry, owing to the generosity of Arthur Guinness, Son and Co., Ltd., who have offered to pay the University $£ 2,500$ a year for seven years for this purpose. The Guinness Research Fellows must be British subjects who are graduates of a university and who have had experience in research. They will be appointed by the Board of the Faculty of Biological Sciences in the University of Oxford, on the recommendation of the Whitley professor of biochemistry and the reader of microbiology in the Department of Biochemistry. It is anticipated that Fellows will hold their appointments for three years, receive a salary between $£ 600$ and $£ 800$ a year and carry out fundamental research in the field of the biochemistry of micro-organisms.

\section{Centenary of the Royal Photographic Society}

The Royal Photographic Society of Great Britain will be celebrating its centenary next year and will hold an international conference on the science and applications of photography in London during September 19-25, 1953. The conference will cover many aspects of the science, technique and applications of photography and will be divided into five sections dealing with the following topics: photographic science-including the theory of the latent image and development, sensitization, sensitometry, resolving power, granularity and the properties of photographic materials ; cinematography and colour photography; technique and applications of photography-including industrial radiography, photomicrography, spectroscopy, aerial photography, photogrammetry, high-speed photography, nuclear track recording, and other physical, chemical and biological applications, as well as photocopying and photographic apparatus, processes and manipulations ; photomechanical processes; history, literature-including abstracting and documentation--and training in photography. All persons taking an interest in photography or its applications are invited to attend the conference, and to submit papers for discussion. Titles and indications of the scope of such papers should be submitted before February 1, 1953, and the full paper before May 1, 1953 ; it is intended to publish the papers in full before the conference. All communication's regarding the conference should be addressed to the Honorary Secretary, R.P.S. Centenary Conference, 16 Princes Gate, London, S.W.7.

Isotope School at Harwell : Course of Instruction

SrNCE the opening in April 1951 of the Ministry of Supply's Isotope School at Harwell, a steady succession of courses has been held there in the technique of handling and using radioactive isotopes. So far, a hundred and fifty scientific workers, medical men and engineers have passed through the school, nearly three-quarters being from Great Britain, and of the remainder one-third being from South Africa, India and Australia and the other two-thirds from European countries. The students come in nearly equal numbers from five main groups: universities, technical colleges and research institutions ; industrial research laboratories; industry; medical centres; and the Department of Scientific and Industrial Research and government departments. Nearly two-thirds of the total have been chemists and biochemists, and the remainder have been made up of engineers, physicists and medical men in roughly equal proportions. During the sixteen months of its existence the School has continually developed and attempted to have in its laboratories equipment which is abreast of the very latest developments all over the world. To house the additional equipment the School was moved from its original quarters, a converted wooden hut, and has, since January of this year, been installed in a permanent brick building where there are now ample facilities for carrying out all the physical and chemical manipulations required when working with radioisotopes. The courses last for four weeks, and in that time, by means of lectures and especially by working in the laboratory, a sound grounding in the principles of working with radioactive materials is given ; the training is intended to be of a fundamental nature and does not deal with the very specialized techniques which have been developed for application in industry and medicine. The next courses in the School will begin in January 1953, and applications for admission and further information can be obtained from Dr. J. E. Johnston, Isotope School, A.E.R.E., Harwell.

\section{Revival of Japanese Botany}

EvIDENCE that the vigorous interest in botanical science that was a feature of pre-war Japan is renewing itself is shown by the publication of "An Address Book of Japanese Botanists" (1951), edited by the National Committee of Botany, and published by the Science Council of Japan, Tokyo (no detailed address given). Some 350 names are given, with ages, addresses, qualifications, interests and publications, and the object is "to recover and further promote our scientific friendship with foreign botanists and relevant societies".

\section{New Photoelectric Absorptiometer}

THE firm of Hilger and Watts, Ltd. (48 Addington Square, London, S.E.5), has recently started to produce a new photoelectric absorptiometer to be known as the 'Now Biochem Absorptiometer'. It is a compact direct-reading instrument of the single-cell type designed for routine use in the laboratory. The controls comprise an on-off switch, a light control for setting the full scale reading, a shutter for the photocell, and a filter selector drum. The latter contains eight spectrum filters of narrow band-width. The photocell is connected to a sensitive reflecting galvanometer the white opaque screen of which enables readings to be taken more easily than with the usual semi-transparent type. Flat-sided cells or special test-tubes can be used, the mount for the latter being optically compensated for the refractive index of the solution. Spilt solutions merely drop through to the work bench; also the cell mounts are made of polythene. The instrument is either batteryor mains-operated with built-in constant-voltage transformer.

\section{Inter-Library Microfilm Catalogue of the Scientific Libraries in Israel}

A BI-LINGUAL guide (in English and Hebrew) to the Inter-Library Microfilm Catalogue of the Scientific Libraries (Natural and Applied Sciences) in Israel has been issued by the Research Council of Israel, Jerusalem (pp. 100; 1952). The catalogue itself is the first part of a scheme to improve the scientific information services of Israel, and, for the present, copies are distributed only to the Research Council of Israel, Jerusalem, the Hebrew University (Terra Santa, Jerusalem), the Agricultural Research Station (Rehovot), the Bett Gordon Library (Dagania A), the Hebrew Institute of Technology (Haifa), and the 